\title{
Analisis Faktor-Faktor yang Mempengaruhi Pendapatan Pedagang di Pasar Tradisional Cinere Depok
}

\author{
Puji Yuniarti
}

\author{
Universitas Bina Sarana Informatika \\ e-mail: puji.pyi@bsi.ac.id
}

\begin{abstract}
Cara Sitasi: Yuniarti, P. (2019). Analisis Faktor-Faktor yang Mempengaruhi Pendapatan Pedagang di Pasar Tradisional Cinere Depok. Widya Cipta, 3(1), 165-170.
\end{abstract}

\begin{abstract}
This study studied what factors influence the income of traders in the Cinere Tradisional Market Depok. This study uses descriptive quantitative research with a total of 50 traders. The sample in this study amounted to 50 respondents taken through the Proportionate Stratified Random Sampling technique. While the data collection method uses questionnaires and interviews. The variables used include education level (XI), Business Capital (X2), Costs (X3), Duration of Business (X4) Working Hours (X5) and merchant income (Y). Data analysis used is multiple linear regression model of ordinary least square (OLS) with a significance level of 5\%. The results of the study showed that the variable partial variables that significantly affect the merchant income of traders Cinere traditional market includes business capital (X2), Costs (X3) and working hours (X5). While the level of education variable (XI) and duration of business (X4) is not suitable for the income of traders in the Cinere Traditional Market Depok. Furthermore, the variables of business capital, costs, and working hour together have a significant effect on the income of traders in the Cinere Traditional market Depok. The influence of dependent variables similarly gave significant influence towards the merchant income was in the percentage of $56,1 \%$ and the remaining $43,9 \%$ is affected by the other variables.
\end{abstract}

Keywords: Education level, Cost, Business capital, Duration, Working hours, and Merchant income

\section{PENDAHULUAN}

Pembangunan di Indonesia saat ini sedang berkembang diberbagai sektor seperti ekonomi, sektor politik, sektor sosial budaya dan lain-lain. Upaya pembangunan tersebut dilakukan untuk meningkatkan taraf hidup masyarakat dan mengantarkan Indonesia memasuki era modernisasi. Pembangunan ekonomi mengarah pada kebijakan yang diambil pemerintah guna mencapai kesempatan kerja dan pertumbuhan ekonomi yang berkelanjutan. Tujuan pembangunan ekonomi sendiri mencakup pengendalian tingkat inflasi dan juga meningkatkan taraf hidup masyarakat. Akan tetapi yang menjadi pokok permasalahan dalam pembangunan ekonomi pada umumnya adalah distribusi pendapatan yang tidak merata (Mithaswari \& Wenagama, 2018).

Pada sektor informal lebih mengutamakan keuletan dan kesabaran serta keterampilan atau keahlian dibandingkan dengan latar belakang pendidikan dan pengalaman kerja. Hal tersebut berbanding terbalik dengan sektor formal dimana sektor formal lebih mengutamakan tenaga kerja yang handal, professional dan memiliki latar belakang pendidikan yang baik guna menunjang peningkatan kinerja perusahaan (Hanum, 2017).
Persaingan dalam dunia bisnis khususnya dalam pbidang usaha memiliki daya saing yang cukup tinggi. Dalam aktivitas perkotaan yang serba gemerlap, keberadaan PKL terasa terasingkan. Harus diakui bahwa keadaan ini timbul karena adanya ketimpangan sosial dan pembangunan serta pendidikan yang tidak merata. Padahal peran PKL sangatlah penting karena dapat mendatangkan sisi positif pada sektor usaha informal. Pilihan masyarakat untuk bekerja di sektor informal dianggap merupakan langkah terbaik saat menghadapi tekanan ekonomi. Usaha pada sektor informal yang dilakukan oleh masyarakat di sekitar ibu kota.

Pilihan masyarakat tersebut dikarenakan bekerja di sektor informal khususnya PKL yang hanya memerlukan modal serta keterampilan yang minim. Pekerjaan sebagai PKL telah dimanfaatkan sebagai pekerjaan utama ataupun sebagai pekerjaan sampingan untuk menambah penghasilan. Keadaan tersebut membuktikan bahwa PKL merupakan salah satu alternatif lapangan pekerjaan untuk mengatasi pengangguran yang ada di perkotaan (Firdausa \& Arianti, 2013).

Pemerintah masih kurang memberikan perhatian kepada pelaku bisnis di sektor informal, sehingga 
menjamurnya para PKL. Pedagang ini sering menggunakan tempat yang digunakan yang menjadi pusat kegiatan umum, seperti di depan toko-toko, trotoar, dekat pusat pendidikan karena menurut mereka tempat- tempat seperti itu adalah tempat yang strategis untuk mereka berdagang (Nuryati, Putri, Sarbawa, \& Astawa, 2018).

Kendala klasik seputar usaha kecil di Indonesia yang sering dibicarakan sampai saat ini adalah soal kekurangan modal, kredit, tenaga kerja, disamping peralatan atau teknologi dan juga pemasaran. Sehingga muncul pertanyaan yang paling esensial dari dampak permasalahan tersebut yaitu bagaimana sektor usaha kecil dalam negeri dapat didorong menjadi sektor usaha berskala besar sehingga memberikan tingkat pendapatan masyarakat yang cukup baik (Agustian, 2015).

Banyak bidang usaha yang berpotensi untuk diangkat dan digali menjadi salah satu bidang usaha yang menghasilkan keuntungan dan income keluarga sekaligus dapat menyerap tenaga kerja. Pedagang kaki lima adalah pedagang kecil yang umumnya berperan sebagai penyalur barang-barang dan jasa ekonomi kota. Dari pengertian tersebut, yang dimaksud dengan pedagang kaki lima adalah setiap orang yang melakukan kegiatan usaha perdagangan atau jasa, yaitu melayani kebutuhan barang-barang atau makanan yang dikonsumsi langsung oleh konsumen, yang dilakukan cenderung berpindah-pindah dengan kemampuan modal yang kecil dan terbatas. Usaha berdagang merupakan salah satu alternatif lapangan kerja usaha kecil, yang ternyata banyak menyerap tenaga kerja, pendapatan pedagang dapat menjadi tumpuan pendapatan keluarga (Hanum, 2017).

\section{Sektor informal}

Sektor informal di Indonesia adalah sektor yang tidak menerima bantuan atau proteksi ekonomi dari pemerintah, sektor yang belum dapat menggunakan (karena tidak mempunyai akses) bantuan, meskipun pemerintah telah menyediakannya dan sektor yang telah menerima bantuan pemerintah tetapi bantuan tersebut belum mampu membuat sektor tersebut mandiri. Aktivitas sektor informal yang dikategorikan sebagai unit usaha kecil bisa bersifat mendukung aktivitas formal dan apabila diberdayakan dan dikembangkan dengan baik akan bersinergi dengan sektor formal perkotaan untuk saling melengkapi kebutuhan warga kota (Suyadi, 2016).

\section{Pedagang Kaki Lima Sebagai Salah Satu Kegiatan Sektor Informal}

Pedagang kaki lima sama dengan hawker, yang didefinisikan sebagai sekelompok orang yang menawarkan barang dan jasa untuk dijual pada ruang publik, terutama di pinggir jalan dan trotoar. Dalam pengertian ini termasuk juga orang yang menawarkan barang dan jasanya dari rumah ke rumah (Rusmusi \& Maghfira, 2018).

Karakteristik menurut jenis usaha dagangan dipergunakan untuk melihat gambaran tentang variasi jenis dagangan yang didagangkan, serta pengaruhnya terhadap pendapatan. Hubungan begitu erat bila dikaitkan dengan masalah pendapatan yang mereka peroleh. Berbagai ragam usaha yang dilakukan oleh masyarakat dalam bentuk usahausaha kecil kaki lima dan semacamnya kemungkinan memberikan dampak positif untuk meningkatkan pendapatan itu sendiri. Jasa pelayanan yang diperdagangkan adalah jasa perorangan, seperti tukang pembuat kunci, tukang potong rambut, tukang reparasi jam dan lain-lain. Pola penyebarannya pada lokasi pusat pertokoan dan pengelompokkannya membaur dengan jenis lainnya. Adapun jenis dagangan yang dijual oleh pedagang bervariasi (Menuk \& Wibowo, 2016).

\section{Pendapatan}

Pendapatan merupakan uang yang diterima oleh seseorang atau perusahaan dalam bentuk gaji (wages), upah (salaries), sewa (rent), bunga (interest), laba (profit) dan sebagainya, bersamasama dengan tunjangan pengangguran, uang pensiun dan sebagainya. Dalam analisis mikroekonomi, istilah pendapatan khususnya dipakai berkenan dengan aliran penghasilan dalam suatu periode waktu yang berasal dari penyediaan faktor-faktor produksi (sumber daya alam, tenaga kerja dan modal) masing-masing dalam bentuk sewa, upah dan bunga maupun laba, secara berurutan. Dalam analisis ekonomi makro, istilah pendapatan nasional (national income) dipakai berkenaan dengan pendapatan agregat suatu negara dari sewa, upah, bunga dan pembayaran, tidak termasuk biaya transfer (tunjangan pengangguran, pensiun dan lain sebagainya) (Hanum, 2017).

Pendapatan diakibatkan oleh kegiatan-kegiatan perusahaan dalam memanfaatkan faktor-faktor produksi untuk mempertahankan diri dan pertumbuhan. Seluruh kegiatan perusahaan yang menimbulkan pendapatan secara keseluruhan disebut earning process. Secara garis besar earning process menimbulkan dua akibat yaitu pengaruh positf (pendapatan dan keuntungan) dan pengaruh negative (beban dan kerugian). Selisih keduanya nantinya menjadi laba atau rugi (Sudrajat, 2014).

Pendapatan merupakan suatu hasil yang di peroleh dari pemakaian kapital dan pemberian jasa perorangan atau keduanya berupa uang, barang materi atau jasa selama jangka waktu yang tertentu. Pendapatan mempunyai pengaruh terhadap pelaku 
sektor informal dari total. Total penerimaan (total revenue) merupakan penerimaan keseluruhan dari hasil penjualan dari output yang dihasilkan (Hanum, 2017).

\section{METODOLOGI PENELITIAN}

a. Populasi dan Teknik Sampel

Populasi dalam penelitian ini adalah para pedagang di pasar tradisional Cinere Depok dengan jumlah responden 50 pedagang. Teknik sampel yang digunakan dalam penelitian ini adalah Simple Random Sampling dan metode pengambilan data menggunakan kuesioner dan wawancara.

\section{b. Teknik Analisis Data}

Untuk mengetahui besarnya pengaruh dari beberapa faktor terhadap pendapatan para pedagang informal di pasar tradisional Cinere, digunakan analisis statistik regresi berganda model dengan formulasi sebagai berikut:

$Y=\alpha+\beta_{1} X_{1}+\beta_{2} X_{2}+\beta_{3} X_{3}+\beta_{4} X_{4}+\beta_{5} X_{5}+e$

Di mana:

$$
\begin{array}{ll}
\mathrm{Y} & =\text { Pendapatan Pedagang } \\
\mathrm{X}_{1} & =\text { Tingkat pendidikan } \\
\mathrm{X}_{2} & =\text { Modal Usaha } \\
\mathrm{X}_{3} & =\text { Biaya } \\
\mathrm{X}_{4} & =\text { Lama Usaha } \\
\mathrm{X}_{5} & =\text { Jam Kerja } \\
\alpha & =\text { Intersep (konstanta) } \\
\beta & =\text { Koefisien Regresi Variabel } \\
\mathrm{e} & =\text { Variabel Pengganggu }
\end{array}
$$

c. Kerangka Konseptual

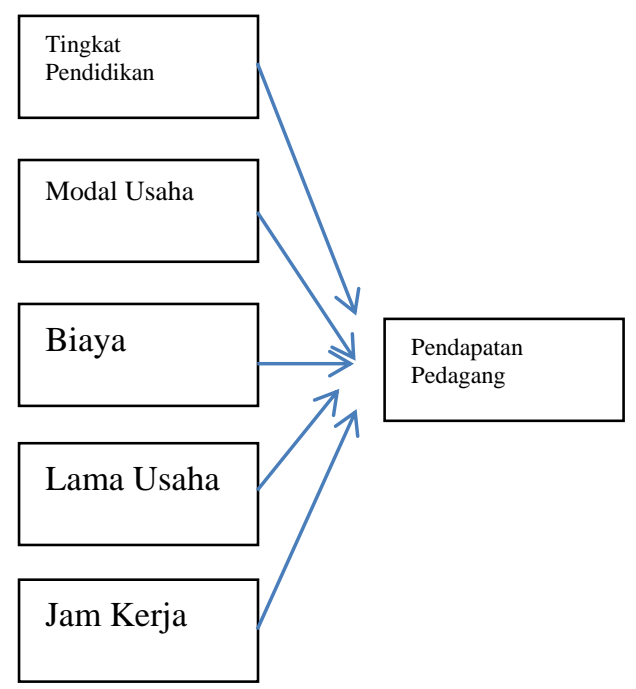

Gambar 1. Kerangka Penelitian

\section{HASIL DAN PEMBAHASAN}

Tabel 1. Jenis Kelamin Pedagang

\begin{tabular}{lll}
\hline Jenis Kelamin & Frekuensi & Persentase \\
\hline Pria & 19 & $38 \%$ \\
\hline Wanita & 31 & $62 \%$ \\
\hline Total & 50 & $100 \%$ \\
\hline
\end{tabular}

Dari tabel di atas menunjukkan bahwa dari 50 pedagang yang diteliti, $38 \%$ berjenis kelamin pria dan $62 \%$ berjenis kelamin wanita

Untuk mengetahui gambaran besar mengenai tingkat pendidikan, modal usaha, biaya, lama usaha, jam kerja, dan pendapatan pedagang di pasar tradisional Cinere Depok, data yang sudah diperoleh disajikan dalam bentuk deskripsi data. Berikut merupakan deskripsi data masing-masing variabel penelitian;

\section{a. Tingkat Pendidikan}

Tingkat pendidikan yang dimaksud merupakan pendidikan formal yang ditempuh atau ditamatkan oleh para pedagang, meliputi tingkat pendidikan SD, SMP, SMA, Perguruan Tinggi dan lainnya.

Berdasarkan hasil kuesioner yang telah diolah dapat diketahui terdapat pedagang yang tidak tamat sekolah dasar sebanyak 10\%, pedagang yang menamatkan SD sederajat $42 \%$, pedagang yang lulusan SMP sederajat sebanyak $24 \%$ dan pedagang yang lulusan SMA sederajat sebanyak $16 \%$ dari total keseluruhan, sedangkan pedagang pasar tradisional yang menamatkan Perguruan Tinggi hanya $8 \%$.

\section{b. Modal Usaha}

Modal usaha dan pendapatan adalah suatu bentuk yang mempunyai hubungan erat. Variabel modal usaha sangat mempengaruhi pendapatan yang diterima pedagang. Modal usaha digunakan oleh pedagang untuk membeli berbagai bahan dagangan dan juga pengolahannya. Berikut tabel modal usaha pedagang pasar tradisional Cinere Depok.

Tabel 2. Frekuensi Modal Pedagang

\begin{tabular}{llll}
\hline Modal Usaha & & Frekuensi & Persentase \\
\hline$<$ Rp. 500.000,- & & 9 & $18 \%$ \\
\hline $\begin{array}{l}\text { Rp. 500.000 - } \\
\text { 1.500.000,- }\end{array}$ & Rp. & 20 & $40 \%$ \\
\hline $\begin{array}{l}\text { Rp. 1.500.000 - } \\
\text { 2.000.000,- }\end{array}$ & & & \\
\hline$>$ Rp. 2.000.000,- & & & $24 \%$ \\
\hline Total & 50 & $12 \%$ \\
\hline
\end{tabular}

Para pedagang memiliki modal usaha per hari dengan modal mulai Rp 500.000,00 sampai di atas Rp. 2.000.000,00. Modal usaha yang paling banyak 
yang dikeluarkan pedagang yaitu modal usaha sebesar Rp 500.000,00 sampai Rp.1.500.000,00 dengan frekuensi 20 pedagang atau sebesar $40 \%$.

\section{c. Biaya}

Biaya yang dimaksud merupakan total biaya yang dikeluarkan oleh pedagang setiap hari berupa biaya operasional, biaya sewa dan retribusi, biaya tenaga kerja/upah dan biaya lainnya (listrik, sampah, transportasi, dan lainnya). Dari hasil pengolahan data kuesioner dapat diperoleh bahwa sebanyak $35 \%$ pedagang mengeluarkan biaya setiap hari di bawah Rp100.000,00, dan 65\% pedagang mengeluarkan biaya di atas Rp100.000,00 setiap harinya.

\section{d. Lama Usaha}

Lama usaha menunjukkan sudah berapa lama pedagang menjalani kegiatan usaha berdagang di pasar, dalam satuan tahun. Secara keseluruhan, para pedagang sudah berdagang lebih dari 1 tahun.Yang paling banyak adalah pedagang yang berjualan selama 5 sampai 10 tahun yaitu sebanyak 30 pedagang atau sebesar $60 \%$.

\section{e. Jam Kerja}

Jam kerja merupakan durasi waktu para pedagang mulai dari membuka usaha sampai menutupnya, dalam satuan jam. Berdasarkan hasil pengolahan kuesioner dapat diketahui bahwa para pedagang membuka usaha antara 5 sampai 10 jam setiap harinya.

\section{f. Pendapatan}

Pendapatan yang diterima pedagang setiap hari merupakan hasil yang diterima dari seluruh omzet penjualan selama satu hari setelah dikurangi biayabiaya, yang dinyatakan dengan satuan rupiah. Berdasarkan data dari hasil kuesioner, besarnya pendapatan pedagang yang diperoleh para pedagang sebesar Rp.100.000,00 sampai Rp 300.000,00 per hari.

Untuk menganalisis dan menjelaskan pengaruh faktor-faktor atau variabel tingkat pendidikan, modal usaha, biaya, lama usaha, dan jam kerja yang mempengaruhi pendapatan pedagang di Pasar Tradisional Cinere Depok, hasil pengolahan data dari kuesioner dianalisis menggunakan regresi linear berganda dengan metode Ordinary Least Square (OLS).

Tabel 3. Koefisien

\begin{tabular}{rrrr}
\multicolumn{1}{c}{ Model } & \multicolumn{1}{c}{$\mathrm{t}$} & \multicolumn{1}{c}{ Sig. } \\
\hline & $\mathrm{X} 1$ & 2,151 &, 383 \\
\cline { 2 - 4 } $\mathrm{X} 2$ & 7,903 &, 000 \\
\cline { 2 - 4 } $\mathrm{X3}$ & 3,091 &, 013 \\
\hline $\mathrm{X} 4$ &, 314 &, 560 \\
$\mathrm{X} 5$ & 1,527 &, 041 \\
\hline
\end{tabular}

\section{a. Dependent Variable: Y}

Berdasarkan hasil pengujian koefisien regresi secara individual dengan uji t menunjukkan bahwa variabel modal usaha (X2), Biaya (X3) dan jam kerja (X5) secara signifikan mempengaruhi tingkat pendapatan pedagang pasar tradisional Cinere (Sig. $\leq 0,05)$. Sedangkan variabel tingkat pendidikan (X1) dan lama usaha (X4) tidak signifikan mempengaruhi tingkat pendapatan pedagang pasar tradisional Cinere (Sig.> 0,05).

Hasil pengujian koefisien regresi secara bersamasama, dengan nilai signifikansi lebih kecil dari 0,05, maka dapat diketahui bahwa variabel-variabel independen (tingkat pendidikan, modal usaha, biaya, lama usaha, dan jam kerja) secara simultan atau bersama-sama mempengaruhi variabel dependen (pendapatan).

\section{Tabel 4.Korelasi}

\begin{tabular}{llrr}
\hline Model & $\mathrm{R}$ & R Square & $\begin{array}{c}\text { Adjusted R } \\
\text { Square }\end{array}$ \\
\hline 1 &, $749^{\mathrm{a}}$ &, 561 &, 317 \\
\hline \multicolumn{2}{l}{ a. Predictors: (Constant), X5, X4, X2, X1, X3 }
\end{tabular}

Berdasarkan hasil analisis tersebut diperoleh nilai $\mathrm{R}^{2}$ sebesar 0,561. Hal ini berarti bahwa variabelvariabel independen (tingkat pendidikan, modal usaha, biaya, lama usaha, dan jam kerja) dalam model mampu menjelaskan variabel dependen (pendapatan) sebesar 56,1\% sedangkan sisanya 43,9\% dijelaskan oleh variabel-variabel lain yang tidak dijelaskan dalam penelitian ini.

Tabel 5. Pendapatan

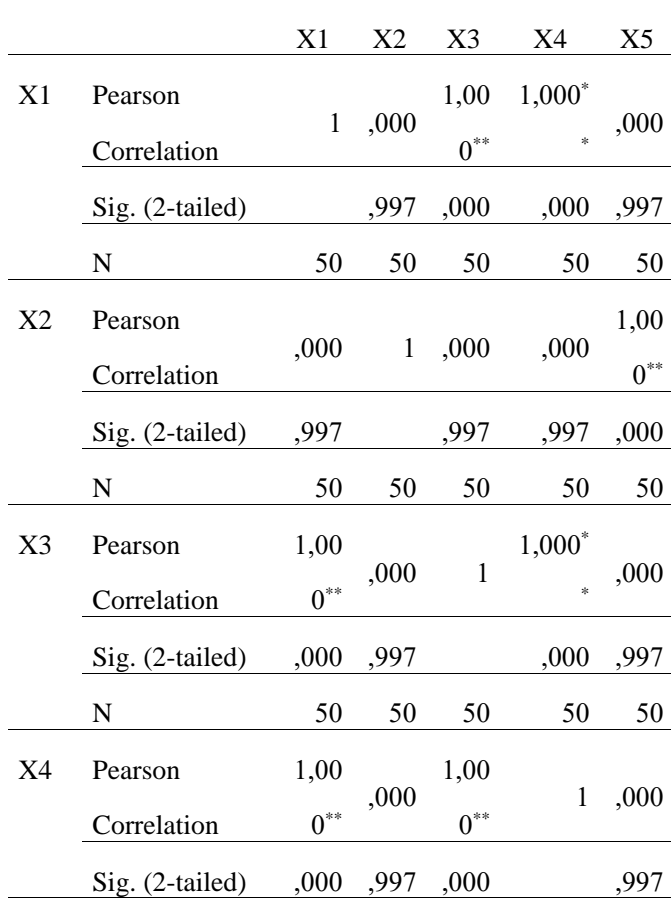




\begin{tabular}{llrrrrr}
\hline \multicolumn{1}{c}{$\mathrm{N}$} & 50 & 50 & 50 & 50 & 50 \\
\hline $\mathrm{X} 5$ & Pearson & & 1,00 & & & \\
& Correlation &, 000 & $0^{* *}$ &, 000 &, 000 & 1 \\
\cline { 2 - 7 } & Sig. (2-tailed) &, 997 &, 000 &, 997 &, 997 & \\
\hline $\mathrm{N}$ & 50 & 50 & 50 & 50 & 50 \\
\hline
\end{tabular}

Tingkat Pendidikan $\left(\mathrm{X}_{1}\right)$

Semakin tinggi pendidikan yang didapat dan ditamatkan maka seseorang dapat mempelajari kemungkinan yang akan terjadi serta lebih berhati-hati dalam setiap pengambilan keputusan.

Dalam penelitian ini, tingkat pendidikan tidak memiliki pengaruh yang signifikan terhadap pendapatan pedagang, hal ini diketahui dari nilai signifikansi variabel tingkat pendidikan yang lebih besar dari 0,05 .

\section{Modal Usaha $\left(\mathrm{X}_{2}\right)$}

Modal usaha merupakan salah satu faktor penting untuk meningkatkan pendapatan usaha kecil. Berdasarkan hasil regresi menunjukkan bahwa pengaruh modal kerja terhadap pendapatan signifikan dengan nilai signifikansi 0,000 yang lebih kecil dari 0,05 Dari sasil koefisien regresi dapat diartikan jika modal kerja bertambah $1 \%$ maka pendapatan usaha kecil akan bertambah sebesar $9,97 \%$, dengan asumsi variabel independennya tetap.

Modal usaha dan pendapatan adalah suatu bentuk yang mempunyai hubungan erat. Variabel modal usaha sangat mempengaruhi pendapatan yang diterima pedagang. Modal usaha digunakan oleh pedagang untuk membeli berbagai bahan dagangan dan juga pengolahannya. Dengan modal yang relatif lebih besar maka akan memungkinkan para pedagang atau pemilik usaha untuk menambah variasi komoditas dagangannya sehingga konsumen relatif lebih tertarik untuk melakukan pembelian barang di tempat tersebut. Hal ini akan dapat meningkatkan pendapatan pedagang.

\section{Biaya $\left(\mathrm{X}_{3}\right)$}

Besarnya biaya yang dikeluarkan oleh pedagang setiap hari untuk mmempengaruhi tingkat pendapatan pedagang. Berdasarkan hasil regresi pada menunjukkan bahwa pengaruh biaya terhadap pendapatan usaha pedagang berpengaruh signifikan dengan nilai sig. Lebih kecil dari 0,05 Dari hasil koefisien regresi dapat diperoleh jika biaya bertambah $1 \%$ maka pendapatan usaha kecil bertambah sebesar 5,3\%, dengan asumsi variabel yang lain tetap.

\section{Lama Usaha $\left(\mathrm{X}_{4}\right)$}

Faktor lama usaha merupakan salah satu faktor yang dapat menentukan kelangsungan dari suatu usaha, karena semakin lama suatu usaha dijalankan, maka usaha tersebut dapat mengembangkan usaha tahap demi tahap. Berdasarkan hasil koefisien regresi menunjukkan bahwa pengaruh lama usaha terhadap pendapatan usaha kecil tidak berpengaruh signifikan dengan nilai sig. yang lebih besar dari 0,05.

Lama usaha berkaitan dengan jangka waktu dari usaha yang dijalankan tersebut, karena semakin lama usaha tersebut berjalan, maka usaha memiliki kelangsungan hidup dan pengembangan.

Implikasi terhadap lamanya usaha yaitu pemilik usaha harus optimis dalam menjalankan usaha yang ada agar menjadi lebih baik di masa yang akan datang, karena pengalaman adalah guru yang baik dimana pengalaman dalam berusaha dapat dijadikan pedoman agar tidak melakukan kesalahan yang pernah terjadi, guna meningkatkan pendapatan usaha kecil.

\section{Jam Kerja $\left(\mathrm{X}_{5}\right)$}

Jam kerja atau buka usaha merupakan faktor yang penting dalam menjalankan kegiatan usaha, karena semakin tinggi jam buka usaha yang kita berikan untuk membuka usaha maka probabilitas omzet yang diterima akan semakin tinggi. Pengaruh jam buka usaha terhadap pendapatan usaha kecil signifikan. Dalam penelitian ini, jam kerja berpengaruh secara signifikan terhadap pendapatan pedagang, hal ini diketahui dari nilai signifikansi variabel jam kerja yang lebih kecil dari 0,05. Dari hasil koefisien regresi dapat diartikan jika jam kerja bertambah $1 \%$ maka pendapatan usaha kecil bertambah sebesar $10,2 \%$, dengan asumsi variabel yang lain tetap.

Implikasi terhadap jam buka usaha yaitu pemilik usaha atau pedagang mesti lebih aktif memanfaatkan jam-jam ramai untuk menjual barang dagangannya, terlebih memperhatikan kualitas barang dagangannya maupun pandai memberikan strategi harga barang guna meningkatkan pendapatan usaha kecil.

\section{KESIMPULAN}

Berdasarkan analisis yang telah dilakukan, dapat diperoleh kesimpulan sebagai berikut modal usaha berpengaruh positif dan signifikan terhadap tingkat pendapatan pedagang, biaya berpengaruh terhadap tingkat pendapatan para pedagang, jam kerja atau waktu buka usaha berdagang sangat berpengaruh terhadap pendapatan para pedagang, tingkat pendidikan tidak berpengaruh terhadap tingkat pendapatan pedagang, dan lama usaha tidak berpengaruh terhadap tingkat pendapatan pedagang. Secara bersama-sama atau simultan variabel tingkat 
pendidikan, modal usaha, biaya, lama usaha, dan jam kerja mempengaruhi pendapatan yang diterima para pedagang,

\section{REFERENSI}

Agustian, W. (2015). Analisis faktor yang mempengaruhi pendapatan pedagang kaki lima di seberang ulu ii plaju. Jurnal Ilmiah MBiA, Volume 14(3), 95-106.

Firdausa, R. A., \& Arianti, F. (2013). Pengaruh Modal Awal, Lama Usaha, dan Jam Kerja terhadap Pendapatan Pedagang Kios di Pasar Bintoro Demak. DIPONEGORO JOURNAL OF ECONOMICS, 2, 1-6.

Hanum, N. (2017). Analisis Faktor-faktor Yang Mempengaruhi Pendapatan Pedagang Kaki Lima di Kota Kuala Simpang oleh Nurlaila Hanum. Jurnal Samudra Ekonomika, 1(1), 72-86.

Menuk, C., \& Wibowo, T. S. (2016). Faktor-faktor yang Mempengaruhi Pendapatan Pedagang Kaki Lima Studi Kasus PKL di Surabaya. Majalah Ekonomi, Volume XXI(1411), 286294.

Mithaswari, I. A. D., \& Wenagama, I. W. (2018). ANALISIS FAKTOR-FAKTOR YANG MEMPENGARUHI Jurusan Ekonomi Pembangunan Fakultas Ekonomi dan Bisnis Unversitas Udayana ( Unud ), Bali, Indonesia. E-Jurnal Ekonomi Pembangunan, 7 no. 2, 294-323.

Nuryati, PUTRI, N. G. A., SUARBAWA, I. W., \& Astawa, I. N. W. (2018). Faktor-faktor yang Mempengaruhi Pendapatan Pedagang di Pasar Kerambitan Tabanan. Majalah Ilmiah Untab, Vol. 15 No, 60-72.
Rusmusi, I., \& Maghfira, A. N. (2018). Pengaruh modal, jam kerja dan lama usaha terhadap pendapatan pedagang. Jurnal Ekonomi, Bisnis, Dan Akuntansi (JEBA), Volume 20, 19.

Sudrajat, A. (2014). Analisis Faktor-faktor yang Mempengaruhi Pendapatan Pedagang Muslim: Studi Pada Pedagang Sayuran di Pasar Jagasatru Cirebon, 8(1), 107-134.

Suyadi, B. (2016). Peranan Sektor Informal dalam Penyerapan Tenaga Kerja dan Peningkatan Pendapatan Nelayan di Wilayah Pantai Pasir Putih Situbondo. Jurnal Pendidikan Ekonomi, 10(2).

\section{PROFIL PENULIS}

Puji Yuniarti, S.E., M.M. lahir di Tanjunguban, Bintan, Kepulauan Riau pada 15 Juni 1977. Lulus dari Program Studi S1 Ekonomi Pembangunan dan S2 Magister Manajemen di Universitas Trisakti Jakarta. Saat ini aktif mengajar sebagai dosen di Fakultas Ekonomi dan Bisnis Universitas Bina Sarana Informatika Jakarta dari tahun 2008 sampai dengan sekarang. Dengan mata kuliah yang diajarkan antara lain Pengantar Ekspor Impor, Metode Penelitian, Bahasa Indonesia, dan Statistika. Lulus dalam uji kompetensi dan memiliki sertifikat kompetensi sebagai Asisten Pelaksana Ekspor yang diselenggarakan oleh Lembaga Sertifikasi Profesi Ekspor Impor Indonesia. 